\title{
A Novel Nicotinic Mechanism Underlies $\beta$-Amyloid-Induced Neuronal Hyperexcitation
}

\author{
Qiang Liu, ${ }^{1}$ Xitao Xie, ${ }^{2}$ Ronald J. Lukas, ${ }^{1}$ Paul A. St. John, ${ }^{3}$ and Jie Wu ${ }^{1,4}$ \\ ${ }^{1}$ Barrow Neurological Institute, St. Joseph's Hospital and Medical Center, Phoenix, Arizona 85013, ${ }^{2}$ Center for Metabolic Biology, Arizona State University, \\ Tempe, Arizona 85287, ${ }^{3}$ Department of Cellular and Molecular Medicine, University of Arizona College of Medicine, Tucson, Arizona 85724, and \\ ${ }^{4}$ Department of Basic Medical Sciences, University of Arizona College of Medicine, Phoenix, Arizona 85004
}

There is a significantly elevated incidence of epilepsy in Alzheimer's disease (AD). Moreover, there is neural hyperexcitation/synchronization in transgenic mice expressing abnormal levels or forms of amyloid precursor protein and its presumed, etiopathogenic product, amyloid- $\beta_{1-42}(\mathrm{~A} \beta)$. However, the underlying mechanisms of how $\mathrm{A} \beta$ causes neuronal hyperexcitation remain unclear. Here, we report that exposure to pathologically relevant levels of $\mathrm{A} \beta$ induces $\mathrm{A} \beta$ form-dependent, concentration-dependent, and time-dependent neuronal hyperexcitation in primary cultures of mouse hippocampal neurons. Similarly, A $\beta$ exposure increases levels of nicotinic acetylcholine receptor (nAChR) $\alpha 7$ subunit protein on the cell surface and $\alpha 7$-nAChR function, but not $\alpha 7$ subunit mRNA, suggesting post-translational upregulation of functional $\alpha 7$-nAChRs. These effects are prevented upon coexposure to brefeldin A, an inhibitor of endoplasmic reticulum-to-Golgi protein transport, consistent with an effect on trafficking of $\alpha 7$ subunits and assembled $\alpha 7$-nAChRs to the cell surface. $\mathrm{A} \beta$ exposure-induced $\alpha 7$-nAChR functional upregulation occurs before there is expression of neuronal hyperexcitation. Pharmacological inhibition using an $\alpha 7$-nAChR antagonist or genetic deletion of nAChR $\alpha 7$ subunits prevents induction and expression of neuronal hyperexcitation. Collectively, these results, confirmed in studies using slice cultures, indicate that functional activity and perhaps functional upregulation of $\alpha 7$-nAChRs are necessary for production of $\mathrm{A} \beta$-induced neuronal hyperexcitation and possibly $\mathrm{AD}$ pathogenesis. This novel mechanism involving $\alpha$-nAChRs in mediation of $\mathrm{A} \beta$ effects provides potentially new therapeutic targets for treatment of AD.

\section{Introduction}

One hallmark of Alzheimer's disease (AD) is the deposition of amyloid- $\beta$ (A $\beta)$ plaques, which is considered to be a result of aberrant amyloid precursor protein (APP) processing and elevated $\mathrm{A} \beta$ production (Goedert and Spillantini, 2006). It still is unclear how $\mathrm{A} \beta$ deposition contributes to neuronal damage, but exposure to pathologically relevant levels of $A \beta$ induces hyperexcitation in individual neurons and neural circuits (Del Vecchio et al., 2004). In AD patients, the incidence of epilepsy (10-22\%) is significantly higher than that in age-matched, non-AD controls $(<1 \%)$ (Amatniek et al., 2006; Hommet et al., 2008). In animals that overexpress $\mathrm{A} \beta$ at pathologically relevant levels, epileptiform activity has been noted in the entorhinal-hippocampal circuit

Received July 7, 2012; revised March 9, 2013; accepted March 12, 2013.

Author contributions: Q.L., R.J.L., P.A.S.J., and J.W. designed research; Q.L., X.X., P.A.S.J., and J.W. performed research; J.W. contributed unpublished reagents/analytic tools; Q.L., X.X., and J.W. analyzed data; Q.L., R.J.L., P.A.S.J., and J.W. wrote the paper.

This work was supported by National Institutes of Health Grants R01 DA015389, U19 DA019377, and U19 MH085193; the Barrow Neurological Foundation; Arizona Biomedical Research Commission Grants 9730 and 9615; Philip Morris USA and Philip Morris International; and a grant from the American Health Assistance Foundation (P.A.S.J.). The authors thank Dr. Michael Sierks for his assistance in atomic force microscopy imaging. The authors also thank Dr. Julie M. Miwa for her helpful comments. The contents of this report are solely the responsibility of the authors and do not necessarily represent the views of the National Institutes of Health or any of the aforementioned awarding agencies.

Correspondence should be addressed to Jie Wu, MD, PhD, Professor, Division of Neurology, Barrow Neurological Institute, 350 West Thomas Road, Phoenix, AZ 85013-4496. E-mail: Jie.Wu@chw.edu.

DOI:10.1523/JNEUROSCI.3235-12.2013

Copyright $\odot 2013$ the authors $\quad 0270-6474 / 13 / 337253-11 \$ 15.00 / 0$
(Palop et al., 2007), and there is a reduction in seizure threshold (Westmark et al., 2008). There are increased $\mathrm{Ca}^{2+}$ transients in neurons near $\mathrm{A} \beta$ plaques (Busche et al., 2008). These findings link $\mathrm{A} \beta$ deposition to neuronal hyperexcitation and aberrant epileptiform activity, which, when combined with responses to this activity, could cause synaptic impairment and cognitive deficits relevant to $\mathrm{AD}$ pathogenesis (Leonard and McNamara, 2007; $\mathrm{Pa}$ lop and Mucke, 2009). However, entities that mediate $\mathrm{A} \beta$ induced neuronal hyperexcitation are largely unknown.

Nicotinic acetylcholine receptors containing $\alpha 7$ subunits ( $\alpha 7$ $n A C h R s)$ have been linked to $\mathrm{A} \beta$ deposition and $\mathrm{AD}$ pathogenesis. Acute exposure to $\mathrm{A} \beta$ alters $\alpha 7$-nAChR function (Liu et al., 2001, 2009; Pettit et al., 2001; Dineley et al., 2002; Lamb et al., 2005). However, there is enhanced expression of $\alpha 7-\mathrm{nAChRs}$ in both $\mathrm{AD}$ patients and $\mathrm{AD}$ model animals (Hellström-Lindahl et al., 1999; Counts et al., 2007; Ikonomovic et al., 2009), even in glial cells (Xiu et al., 2005; Yu et al., 2005), and $\alpha 7$-nAChR function is not reduced in adult (7-month-old) APP transgenic mice (Spencer et al., 2006). Thus, longer-term exposure to A $\beta$ may enhance rather than reduce $\alpha 7$-nAChR expression and function in both $\mathrm{AD}$ patients and animal models, which is possibly relevant to $\mathrm{AD}$ progression.

$\alpha 7$-nAChRs play important roles in regulating neuronal excitability (Dani, 2000; McKay et al., 2007). $\alpha 7$-nAChRs have high $\mathrm{Ca}^{2+}$ permeability (Bertrand et al., 1992), and their activation elevates presynaptic glutamate release (Dani, 2000; McKay et al., 2007), both of which could contribute to neuronal hyperexcita- 
tion. In addition, animals with gain-of-function $\alpha 7$-nAChR mutations exhibit significantly higher susceptibility to seizures (Broide et al., 2002). Disrupting interactions of $\mathrm{A} \beta$ with $\alpha 7$ $\mathrm{nAChRs}$ is reported to diminish $\mathrm{A} \beta$ toxicity (Wang et al., 2009), and genetic deletion of nAChR $\alpha 7$ subunits significantly rescues synaptic impairment and learning/memory deficits in APP mice (Dziewczapolski et al., 2009). Collectively, this evidence suggests the hypothesis that chronic exposure to pathologically relevant levels of $\mathrm{A} \beta$ upregulates $\alpha 7$-nAChR function, which then contributes to neuronal hyperexcitation.

In this study, we test this hypothesis using multiple approaches with mouse primary neuronal and slice cultures. We find that exposure to nanomolar concentrations of $A \beta$ first induces increased expression and function of $\alpha 7$-nAChRs, and then induces neuronal hyperexcitation.

\section{Materials and Methods}

Primary cell culture. The protocol for preparation of primary neuronal cultures was approved by the Institutional Animal Care and Use Committee of the Barrow Neurological Institute and St. Joseph's Hospital and Medical Center. Wild-type (WT) C57/BL, nAChR $\alpha 7$ subunit knock-out $(\mathrm{KO})$, and glutamic acid decarboxylase-green fluorescent protein (GADGFP) mice (provided by Dr. Scott C. Steffensen, Brigham Young University) were used in this study. As we previously described (He et al., 2012), the day before culture, poly-D-lysine $0.02 \%$ solution was added to culture dishes. Dishes were swirled to make sure the entire bottom was coated, and then dishes were left in a $37^{\circ} \mathrm{C}, 5 \% \mathrm{CO}_{2}$ incubator overnight. The next day, dishes were washed three times with sterile water and left in the incubator after the final wash. One-to-three-day-old mice (of either gender) were killed, and hippocampal CA1-CA3 regions were dissected under a stereo microscope. Tissue was minced with scissors in ice-cold Neurobasal medium (Invitrogen) and then digested with Papain (20 $\mathrm{U} / \mathrm{mg}$; Worthington) at $30^{\circ} \mathrm{C}$ for $20 \mathrm{~min}$ in tubes shaken at $120 \mathrm{rpm}$ in a water bath shaker. After enzyme digestion, the reaction was stopped by adding inactivated fetal bovine serum into the medium. Then, digested tissue was filtered and transferred into $15 \mathrm{ml}$ tubes. After trituration, tissue was centrifuged at $1500 \mathrm{rpm}$ for $3 \mathrm{~min}$ to form pellets containing dissociated cells, and the supernatant was removed and replaced with Neurobasal medium, which was used to resuspend the pellets. This process was repeated three times. After the final centrifugation, the supernatant was replaced with Neurobasal medium containing $0.03 \mathrm{~mm}$ choline chloride and supplemented with $0.5 \%(\mathrm{w} / \mathrm{v})$ L-glutamine and 2\% B27 serum-free supplement. Cells were resuspended, counted based on Trypan blue exclusion, and plated at a density of $4.5-5.0 \times 10^{4}$ cells per $\mathrm{cm}^{2}$ in $35 \mathrm{~mm}$ culture dishes. Cells were kept within the $37^{\circ} \mathrm{C}, 5 \% \mathrm{CO}_{2}$ incubator for future use.

Organotypic slice cultures. Organotypic slice cultures were prepared from newborn WT C57/BL mouse pups as previously described (Stoppini et al., 1991; De Simoni and Yu, 2006). Briefly, brains were removed from killed, 0-1-d-old mice and placed in minimal essential medium (Invitrogen). Brain tissues, including cortex and hippocampus, were dissected, and coronal slices $(300 \mu \mathrm{m})$ were generated using a vibratome (Vibratome), placed onto Millicell-CM culture membranes (Millipore), and transferred to six-well plates filled with $1.2 \mathrm{ml}$ of culture medium [per $100 \mathrm{ml}: 50 \mathrm{ml}$ of Basal Medium Eagle, $25 \mathrm{ml}$ of EBSS, $23 \mathrm{ml}$ of horse serum, $0.5 \mathrm{ml}$ of Glutamax (200 mM stock), $0.1 \mathrm{ml}$ of gentamicin (10 $\mathrm{mg} / \mathrm{ml}$ stock $), 0.4 \mathrm{ml}$ of fungizone $(250 \mu \mathrm{g} / \mathrm{ml})$, and $1.45 \mathrm{ml}$ of D-glucose $(45 \% ; 42 \mathrm{~mm}$ total) $]$. Cultures were then incubated in humidified, $5 \%$ $\mathrm{CO}_{2}$ at $36-37^{\circ} \mathrm{C}$, with medium changes every $2 \mathrm{~d}$. After $7 \mathrm{~d}$ in vitro, media was replaced with $1.2 \mathrm{ml}$ of serum-free media [per $\sim 100 \mathrm{ml}: 97 \mathrm{ml}$ of Neurobasal, $2 \mathrm{ml}$ of B27, $0.5 \mathrm{ml}$ of Glutamax (200 mM), $0.1 \mathrm{ml}$ of ascorbic acid $(0.5 \mathrm{M})$, and $0.68 \mathrm{ml}$ of D-glucose $(45 \% ; 42 \mathrm{~mm}$ total $)]$.

Electrophysiology. The standard external solution contained $140 \mathrm{~mm}$ $\mathrm{NaCl}, 3 \mathrm{~mm} \mathrm{KCl}, 2 \mathrm{~mm} \mathrm{MgCl}_{2}, 2 \mathrm{~mm} \mathrm{CaCl} 2,10 \mathrm{~mm}$-glucose, $10 \mathrm{~mm}$ HEPES, pH 7.4 with Tris base. The pipette solution for current-clamp recordings used to measure intrinsic excitability contained $130 \mathrm{mM}$ $\mathrm{KMeSO}_{4}, 10 \mathrm{~mm} \mathrm{KCl}, 10 \mathrm{~mm}$ HEPES/K-HEPES, $2 \mathrm{~mm} \mathrm{MgSO}_{4}, 0.5 \mathrm{~mm}$
EGTA, and 3 mm ATP, pH 7.3 with KOH. For miniature EPSC (mEPSC) recordings, $0.3 \mu \mathrm{M}$ TTX, $50 \mu \mathrm{M}$ picrotoxin, and $50 \mu \mathrm{M}$ APV were added to the external solution to block voltage-gated sodium channels, $G_{A B A}$ receptors, and glutamate receptors. For whole-cell recording of ligandgated ion channel activity and for mEPSC recordings, the pipette solution contained $140 \mathrm{~mm}$ potassium gluconate, $5 \mathrm{~mm} \mathrm{KCl,} 10 \mathrm{~mm}$ HEPES, $0.2 \mathrm{~mm}$ EGTA, $2 \mathrm{~mm} \mathrm{MgCl}_{2}$, 4 mu MgATP, $0.3 \mathrm{~mm} \mathrm{Na}_{2} \mathrm{GTP}$, and $10 \mathrm{~mm}$ $\mathrm{Na}_{2}$-phosphocreatine, $\mathrm{pH} 7.3$ with $\mathrm{KOH}$. Current-clamp recordings to measure neuronal excitability were performed using subtle modifications of a previously described protocol (Desai et al., 1999; Karmarkar and Buonomano, 2006). Recordings were considered acceptable only if cells exhibited overshooting action potentials and their resting membrane potential did not vary by $>5 \mathrm{mV}$. The input resistance was required to be $>80 \mathrm{M} \Omega$ and to vary $<15 \%$ during recordings. Neuronal intrinsic excitability was measured as the number of spikes in response to a series of fixed, 2 or $4 \mathrm{~s}$ ms current injection steps $(0,30,60,90,120,150$, or $180 \mathrm{pA})$. In whole-cell recordings, peak currents and cell membrane capacitance as an indication of membrane area were used to calculate current densities. Data were acquired at $2 \mathrm{kHz}$ using an Axopatch 200B amplifier and pClamp 9.2 software (Molecular Devices) and analyzed using clampfit 9.2 (Molecular Devices) and Mini Analysis (Synaptosoft) software as previously described (Liu et al., 2009).

Drugs, $A \beta$ preparation, and $A \beta$ treatment. Drugs used in this study were choline (Sigma-Aldrich), (-)nicotine, methyllycaconitine (MLA), dihydro- $\beta$-erythroidine (DH $\beta$ E) (Sigma-Aldrich), AMPA (Tocris Bioscience), NMDA (Tocris Bioscience), GABA (Sigma-Aldrich), TTX (Tocris Bioscience), brefeldin A (BFA; Calbiochem), scrambled $A \beta_{1-42}$, and authentic $\mathrm{A} \beta_{1-42}(\mathrm{~A} \beta$; rPeptide). Whenever the abbreviation $\mathrm{A} \beta$ is used in the text (except for the introduction) we refer to $A \beta_{1-42}$, and we specify the form when relevant. A $\beta$ peptides were dissolved in $1,1,1,3,3,3$ hexafluoro-2-propanol at a concentration of $1 \mathrm{mg} / \mathrm{ml}$ in $250 \mu \mathrm{l}$ of aliquots, air dried, and stored at $-20^{\circ} \mathrm{C}$. Aliquots were resuspended in dimethyl-sulfoxide and further diluted in PBS, $\mathrm{pH} 7.4$, to a final concentration of $100 \mu \mathrm{M}$ and incubated at $37^{\circ} \mathrm{C}$ without shaking. Oligomeric aggregates of $A \beta$ were obtained after incubation for $6 \mathrm{~h}$. For fibril formation, $\mathrm{A} \beta$ was incubated at $37^{\circ} \mathrm{C}$ for at least $96 \mathrm{~h}$. Both oligomeric and fibrillar forms were verified by atomic force microscopy (AFM) before being added into culture medium. Primary cultured neurons were maintained at $37^{\circ} \mathrm{C}$ in a humidified atmosphere of $5 \% \mathrm{CO}_{2} / 95 \%$ air for $14 \mathrm{~d}$ before $\mathrm{A} \beta$ treatments, which involved renewing $\mathrm{A} \beta$-containing culture medium (100 nM) daily for $0-10 \mathrm{~d}$. The same renewal procedure with medium containing scrambled $\mathrm{A} \beta_{1-42}$ (containing the same amino acids, but in random order) was performed as a control. For pharmacological studies, nAChR antagonists (MLA or DH $\beta$ E) were applied chronically along with $\mathrm{A} \beta$ for $7 \mathrm{~d}$, or there was subchronic ( $10 \mathrm{~min}$ ) exposure to MLA or $\mathrm{DH} \beta \mathrm{E}$ after a prescribed period of $\mathrm{A} \beta$ exposure before testing for neuronal hyperexcitation or mEPSC studies.

Electron microscopy. The aggregation forms of $\mathrm{A} \beta$ used in this study were determined in part by negative-staining electron microscopy (EM). Immediately before use in slice or cell culture studies, $2 \mu \mathrm{l}$ of aliquots from $100 \mu \mathrm{M}$ stock solutions were adsorbed for $1 \mathrm{~min}$ to the surface of plastic-coated, carbon-backed, 300-mesh copper grids, which were blotted to remove excess liquid and covered with $5 \mu$ l of $2 \%$ aqueous uranyl acetate for $2 \mathrm{~min}$. Then, excess liquid was removed, and samples were allowed to air dry and then stored. Subsequently, samples were viewed at 34,000-175,000 $\times$ magnification using a Philips CM12 electron microscope (Fig. 1C), and images were collected with an AMT XR40 digital camera (Advanced Microscopy Techniques). Sizes were calibrated by comparison to sizes of catalase crystal standards (Ted Pella).

AFM imaging. AFM also was used to monitor the morphology of $\mathrm{A} \beta$ aggregates before experiments. Aliquots were removed from $A \beta$ stock samples and immediately spotted on freshly cleaved mica. After 2 min, the mica was washed with $1 \mathrm{ml}$ of deionized water, and then dried with compressed nitrogen for storage. Subsequently, topographic AFM images were obtained in air at room temperature using a tapping mode AFM with a Nanoscope IIIa controller (Veeco). Images were acquired using oxide-sharpened $\mathrm{Si}_{3} \mathrm{~N}_{4}$ AFM tips $\left(k=40 \mathrm{~N} / \mathrm{m} ; f_{\mathrm{o}}, \sim 300 \mathrm{kHz}\right)$ (OTESPA, Veeco) at scan rates of 2-3 Hz and at scan resolution of 512 samples per line (Fig. 1D). Images were subjected to second-order poly- 

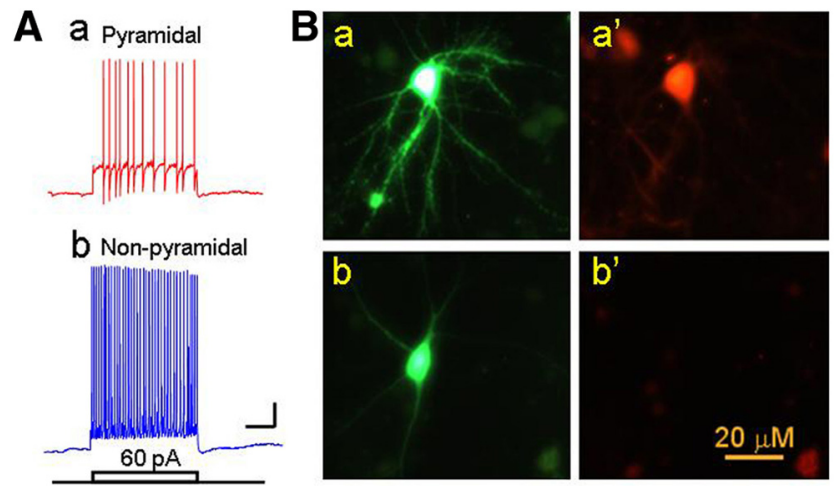

\section{C}

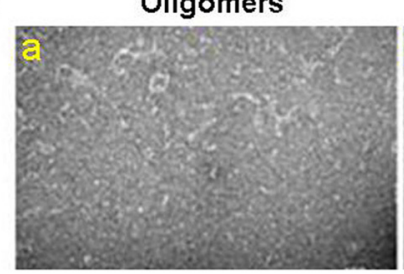

D
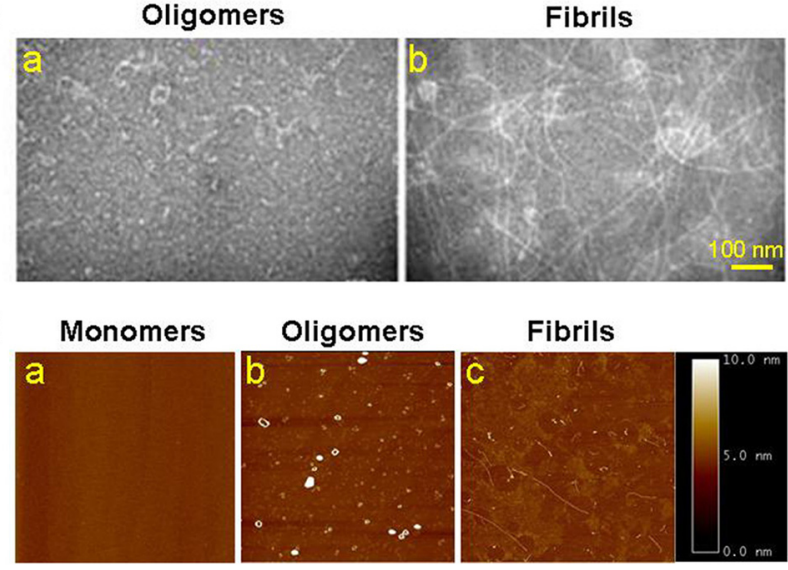

Fibrils

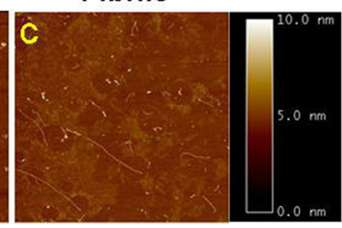

Figure 1. Identification of neuronal phenotypes of cultured hippocampal neurons and determination of $A \beta$ forms. $A, A P$ firing rates and their responses to injection of $60 \mathrm{pA}$ of current were determined using current-clamp recording and used initially to distinguish pyramidal-like $(\boldsymbol{A a})$ from nonpyramidal-like $(\boldsymbol{A b})$ neurons in primary hippocampal cultures. The scale bars indicate a $0.5 \mathrm{~s}$ interval (horizontal) or a $10 \mathrm{mV}$ membrane potential change (vertical). $\boldsymbol{B}$, The recorded neurons in $\boldsymbol{A}$ were further labeled by postrecording injection of biocytin and subsequent reaction with streptoavidin $(\boldsymbol{B} \boldsymbol{a}, \boldsymbol{B} \boldsymbol{b})$ but distinguished based on neurogranin $\left(\boldsymbol{B a}^{\prime}, \boldsymbol{B} \boldsymbol{b}^{\prime}\right)$ immunostaining (calibration bar, $20 \mu \mathrm{m}) . \boldsymbol{C}, \boldsymbol{D}, \mathrm{EM}(\boldsymbol{C})$ or AFM (D) were used to monitor aggregation forms of $A \beta$ made as described in Materials and Methods and then used in this study. Preparations of $A \beta$ in the form of oligomers (at a concentration of $100 \mathrm{~nm}$ equivalent of $A \beta$ monomer) contained short, irregular rods, globules, and some rings as evident in EM (Ca) or AFM $(\boldsymbol{D b})$ images (C: scale bar, $100 \mathrm{~nm}$; $\boldsymbol{D}$ : particle size is color-coded as on the right-hand panel). Fibril preparations ( 100 nm equivalent of $A \beta$ monomer) are enriched for long fibrils as seen on EM $(\boldsymbol{C} \boldsymbol{b})$ or AFM $(\boldsymbol{D} \boldsymbol{c})$ images. These results indicate our ability to prepare and define specific forms of $A \beta$.

nomial flattening as needed to reduce the effects of image bowing and tilt. AFM images were analyzed with Scanning Probe Imaging Processor software (Image Metrology, www.imagemet.com) to generate height distribution histograms for each sample.

Immunostaining. After whole-cell current recording sessions had ended, cells from hippocampal neuronal cultures were injected with biocytin $(5 \mathrm{mg} / \mathrm{ml}$, included in recording electrodes and infused into the intracellular space by converting to true, whole-cell recording mode) while still in their $35 \mathrm{~mm}$ culture dishes. Cells then were fixed in $4 \%$ paraformaldehyde for $10 \mathrm{~min}$ and washed at room temperature with PBS three times for 5 min each. Then, a PBS-based blocking solution containing 5\% normal goat serum and $0.3 \%$ Triton X-100 was applied for $1 \mathrm{~h}$. After incubation at $4^{\circ} \mathrm{C}$ overnight with primary, goat anti-neurogranin antibody (1:100 dilution; Santa Cruz Biotechnology), cultures were washed with PBS three times for $5 \mathrm{~min}$ each. Thereafter, Avidin-AF488 (1:1000 dilution; Invitrogen) was added to fluorescently label biocytincontaining cells subject to recording. Alexa 555-conjugated anti-goat secondary IgG (Invitrogen) was applied in blocking solution for $2 \mathrm{~h}$ at room temperature to interact with immobilized, anti-neurogranin anti- bodies to confirm identity of pyramidal neurons (Fig. $1 B$ ). The cultures were then finally washed three times for 5 min each with PBS and prepared for fluorescence microscopy.

Affinity isolation of $\alpha 7-n A C h R s$. To capture $\alpha 7-n A C h R s$ expressed on cell surfaces of cultured, primary hippocampal cells, we used a modification of a previously described protocol (Charpantier et al., 2005). Cells were maintained for $30 \mathrm{~min}$ in the culture incubator in media containing or in the absence of $10 \mu \mathrm{M}$ nonbiotinylated $\alpha$-bungarotoxin ( $\alpha$-Bgt). Thereafter, $300 \mathrm{~nm}$ biotinylated $\alpha$-Bgt was added to the medium for 45 min. Cells were then washed three times with PBS and lysed as described previously (Charpantier et al., 2005) to solubilize membrane-associated proteins. Streptavidin-agarose beads were added to precipitate surface $\alpha 7$-nAChRs bound to biotinylated $\alpha$-Bgt. Total (from the cell surface and from intracellular pools) $\alpha 7-\mathrm{nAChR}$ assemblies were isolated by adding $300 \mathrm{~nm}$ biotinylated $\alpha$-Bgt alone or in the presence of $10 \mu \mathrm{M}$ unlabeled $\alpha$-Bgt to separately processed cell lysates, followed by reaction with streptavidin-agarose beads. Beads were pelleted by centrifugation at $14,000 \times g$, and the supernatants from samples were transferred to new tubes. The BCA protein assay (Pierce) was used to determine protein concentrations in cell lysates. Affinity isolated samples were resolved according to mass by SDS-polyacrylamide gel electrophoresis, transferred to nitrocellulose membranes (Bio-Rad), and immunoblotted using a goat anti- $\alpha 7$ subunit antibody (1:100; H302, Santa Cruz Biotechnology) overnight at $4^{\circ} \mathrm{C}$. After membranes were washed, horse radish peroxidase-conjugated anti-goat secondary antibody (Santa Cruz Biotechnology) was added and incubated for $1 \mathrm{~h}$ at room temperature. $\alpha 7$ Subunit-like immunoreactive material was then visualized after reaction using an enhanced chemiluminescence kit (GE Healthcare BioSciences) and quantified using ImageJ software $1.45 \mathrm{~s}$ (National Institutes of Health, Bethesda, MD).

Quantitative real-time PCR. Total RNA from primary neuronal cultures was extracted using column purification (Qiagen). Firststrand cDNA was generated with random primers using iScript cDNA synthesis kits (Bio-Rad). Real-time analysis was performed on a BioRad ICycler system (Bio-Rad) using the following conditions: an initial denaturation for $10 \mathrm{~min}$ at $95^{\circ} \mathrm{C}$, followed by 40 cycles of $15 \mathrm{~s}$ of denaturation at $95^{\circ} \mathrm{C}, 30 \mathrm{~s}$ of annealing at $60^{\circ} \mathrm{C}$, and $1 \mathrm{~min}$ extension at $72^{\circ} \mathrm{C}$. Analysis was performed according to the $\Delta \Delta \mathrm{Ct}$ method using GAPDH as the housekeeping gene standard. The primer sequences are as follows: ACHA7, 5' -TTGATGCCACGTTCCACACCAATG-3' and 5'-AGGGAACCAGCGAACGTCAATGTA-3' ; ACHB2, 5' -ACAA TGCTGACGGCATGTACGA-3' and 5'-TGCTGGTCAAATGGGAA GTGCT-3'; and GAPDH, 5'-TGACTCTACCCACGGCAAGTTC AA- $3^{\prime}$ and 5'-ACGACATACTCAGCACCAGCATCA-3'.

Data analysis and statistics. Data are given as mean \pm SEM with numbers of determinations $(n)$. A probability level of $p<0.05$ was considered to be statistically significant based on two-tailed Student's $t$ tests, oneway or two-way ANOVA followed by appropriate tests.

\section{Results}

\section{Identification of cell phenotype}

Pyramidal cells in mouse primary hippocampal cultures were initially and tentatively identified based on their morphology, and their identities were then validated by characterization based on their electrophysiological features [Fig. 1A; slower action potential (AP) firing rates (Fig. 1Aa) than those seen for nonpyramidal neurons (Fig. 1Ab) upon injection of $60 \mathrm{pA}$ currents] (Alkondon and Albuquerque, 1995). Recorded neurons were positively identified by postrecording injection of biocytin and reaction with fluorescent avidin (Fig. $1 B a, B b$ ) and had identities subsequently confirmed by immunostaining following patchclamp recording as either neurogranin-positive pyramidal neurons (Fig. $1 \mathrm{Ba}^{\prime}$ ) or neurogranin-negative nonpyramidal neurons (Fig. $\left.1 B b^{\prime}\right)$. 
Chronic A $\boldsymbol{\beta}$ fibril treatment induces neuronal hyperexcitation

In identified pyramidal neurons, we compared effects of exposure to fibrillar $A \beta$ or scrambled $A \beta$ (a peptide made with the same amino acid composition as $\mathrm{A} \beta$, but in random sequence and used as a nonaggregating control) on neuronal excitability. Throughout, we determined the aggregation state or form of $\mathrm{A} \beta$ using $\mathrm{EM}$ (Fig. 1C) and AFM (Fig. 1D), confirming that preparations were either oligomeric (Fig. $1 C a, D b$ ) or fibrillar (Fig. $1 C b, D c$ ).

In hippocampal pyramidal neurons treated with $100 \mathrm{~nm}$ scrambled $\mathrm{A} \beta$ for $7 \mathrm{~d}$, few spontaneous APs were observed (Fig. $2 A a$ ), whereas in neurons treated with 100 $\mathrm{nM}$ fibrillar $\mathrm{A} \beta$ (concentration indicated is in monomeric $A \beta$ equivalents) for $7 \mathrm{~d}$, there was spontaneous bursting of APs (Fig. 2Ac). To define changes in neuronal excitability after $\mathrm{A} \beta$ treatment, we assessed effects of injection of depolarizing current into cells on neuronal activity (Desai et al., 1999; Karmarkar and Buonomano, 2006). Treatment for $7 \mathrm{~d}$ with 100 $\mathrm{nM} \mathrm{A} \beta$ fibrils significantly increased neuronal AP spiking activity in response to injected currents ( 90 pA; Fig. $2 A d$ ) when compared with results from cells treated with $100 \mathrm{~nm}$ scrambled $\mathrm{A} \beta$ (Fig. $2 A b$ ). In mouse organotypic cultured hippocampal slices, $100 \mathrm{~nm} \mathrm{~A} \beta$ fibril treatment for $7 \mathrm{~d}$ also increased CA1 pyramidal neuronal excitability (Fig. $2 B b$ ) relative to effects of scrambled $\mathrm{A} \beta$ (Fig. $2 \mathrm{Ba}$ ). To quantify changes in neuronal excitability after $A \beta$ treatment, we measured input-output relationships that derived from plots of spike numbers occurring each $4 \mathrm{~s}$ as a function of injected, depolarizing current amplitude (Desai et al., 1999; Karmarkar and Buonomano, 2006). For injected currents of 30-180 $\mathrm{pA}$, numbers of APs were significantly increased above control levels by A $\beta$ fibril exposure (Fig. $2 C$; in cultured neurons, $n=24$ for $\mathrm{A} \beta$ fibril treatment; $n=16$ for scrambled $\mathrm{A} \beta$ treatment; Fig. $2 D$; in cultured slices, $n=8$ for $\mathrm{A} \beta$ fibril treatment; $n=8$ for scrambled $\mathrm{A} \beta$ treatment; ${ }^{\star} p<0.05 ;{ }^{* *} p<0.01, t$ test). We also measured changes relative to resting potential in membrane potential in response to depolarizing current injection (Fig. $2 A b$, $A d, B a$, and $B b$, traces). In 16 neurons treated with scrambled $A \beta$, $90 \mathrm{pA}$ current injection depolarized the membrane potential by $9.4 \pm 0.8 \mathrm{mV}$, whereas in 24 neurons treated with fibrillar $\mathrm{A} \beta$, the membrane potential depolarized by $13.6 \pm 1.7 \mathrm{mV}$ (Fig. $2 E$; $t$ test, ${ }^{* *} p<0.01$ ). In addition, exposure for $7 \mathrm{~d}$ to $100 \mathrm{~nm} \mathrm{~A} \beta$ fibrils caused an increase in resting input resistance in cultured hippocampal pyramidal neurons compared with effects in scrambled $\mathrm{A} \beta$-treated controls $(\mathrm{A} \beta$ scrambled: $580 \pm 67 \mathrm{M} \Omega, n=8$; $\mathrm{A} \beta$ fibril: $860 \pm 88 \mathrm{M} \Omega, n=8$; $t$ test, ${ }^{* *} p<0.01$; data summarized, but figure not shown), consistent with an increase in neuronal excitability (Fan et al., 2008; Mongiat et al., 2009). In hippocampal primary cultures and cultured slices, we also found significantly larger increase in membrane potential responses to injected current after fibrillar $\mathrm{A} \beta$ exposure relative to effects in the presence of control, scrambled $A \beta$ (Fig. $2 E$ ). These results indicate that exposure of mouse hippocampal primary or slice cultures to $100 \mathrm{~nm} \mathrm{~A} \beta$ fibrils for $7 \mathrm{~d}$ induces pyramidal neuron hyperexcitation.

\section{Time-dependent, concentration-dependent, and form-} dependent effects of $A \boldsymbol{\beta}$ exposure on neuronal excitability To define temporal patterns of $A \beta$ exposure on intrinsic excitability, we treated mouse primary hippocampal cultures with 100 nм $\mathrm{A} \beta$ fibrils for $0,1,4,7$, or $10 \mathrm{~d}$ and monitored pyramidal neuronal responses to $90 \mathrm{pA}$ current injection. Time-dependent effects were evident from current-clamp recordings (Fig. 3Aa). Effects of $\mathrm{A} \beta$ fibril treatment for 7 or $10 \mathrm{~d}$ on AP spike numbers (Fig. $3 A b$; $t$ test, ${ }^{* *} p<0.01$ ) and membrane potential depolarization (Fig. $3 A c ;{ }^{* *} p<0.01, t$ test) in response to $90 \mathrm{pA}$ current injection were significantly higher than for scrambled peptidetreated controls.

$\mathrm{A} \beta$ exists in a variety of different forms, these being soluble monomers, small oligomeric aggregates (e.g., dimers to dodecamers), or large, plaque-forming, fibrillar aggregates. These different forms of $A \beta$ exhibit different effects on neurons, neural circuits, and neural networks (Bucciantini et al., 2002; Tsai et al., 2004; Cleary et al., 2005; Shankar et al., 2008). Here, we found that $7 \mathrm{~d}$ of exposure of cultured primary hippocampal pyramidal neurons to $100 \mathrm{~nm}$ fibrillar $\mathrm{A} \beta$ produced significantly $\left({ }^{* *} p<\right.$ 0.01 , 1-way ANOVA) increased neuronal excitability whether measured as spike numbers (Fig. $3 \mathrm{Ba}$ ) or by the extent of membrane potential depolarization (Fig. $3 B b$ ) induced by 90 pA cur- 
A
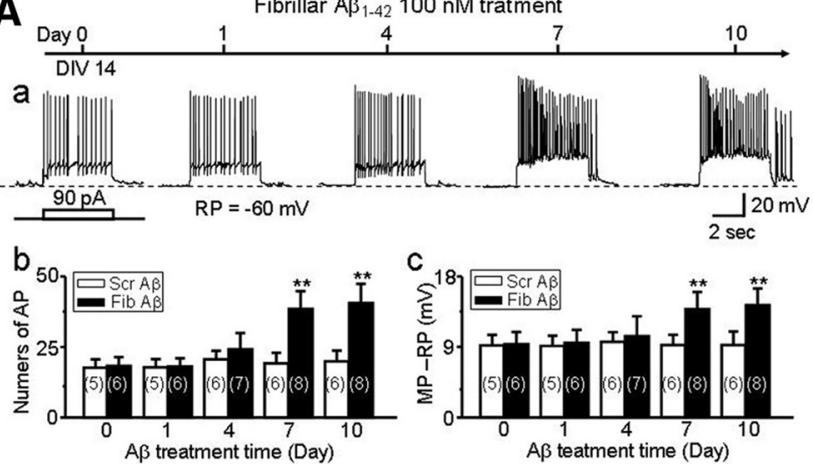

$\mathbf{B}_{\mathrm{a}}$
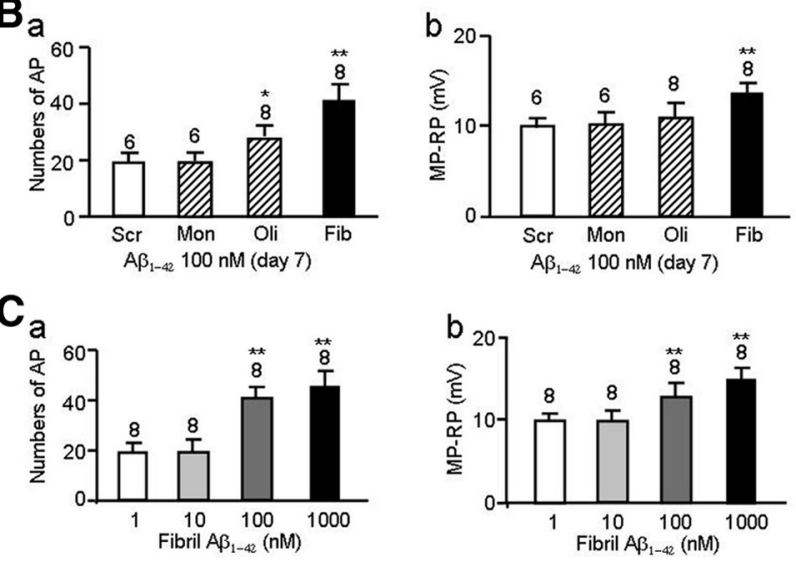

Figure 3. Time-dependent, concentration-dependent, and form-dependent effects of $A \beta$ on neuronal excitability. $\boldsymbol{A}$, Sample traces $(\boldsymbol{A} \boldsymbol{a})$ of effects of $100 \mathrm{~nm}$ (equivalent of $A \beta$ monomers) fibrillar $A \beta$ exposure for the indicated periods on membrane excitability recorded during $90 \mathrm{pA}$ current injection from hippocampal pyramidal neurons. Note the membrane potential change and time scale calibration bars. Bar graph summarizing the data indicates that $100 \mathrm{~nm}$ $A \beta$ fibril exposure (filled bars) significantly increased spike number after 7 or $10 \mathrm{~d}$ of treatment relative to scrambled $A \beta$-treated controls (open bars) $\left(\boldsymbol{A} \boldsymbol{b},{ }^{* *} p<0.01, t\right.$ test), and membrane potential changes relative to resting potential $\left(\boldsymbol{A} \boldsymbol{c}_{,}{ }^{* *} p<0.01, t\right.$ test). $\boldsymbol{B}$, Bar graphs summarize results as numbers of AP spikes counted $(\boldsymbol{B} \boldsymbol{a})$ or changes in membrane potential $\left(\boldsymbol{B} \boldsymbol{b},{ }^{*} p<\right.$ 0.05 , ${ }^{* *} p<0.01$, 1-way ANOVA) following exposure for $7 \mathrm{~d}$ to $100 \mathrm{~nm}$ of the indicated $A \beta$ forms (Scr, scrambled; Mon, monomeric; Oli, oligomeric; Fib, fibrillar). C, Bar graphs summarizing concentration studies illustrate that $100 \mathrm{~nm}$ or $1 \mu \mathrm{m} \mathrm{A} \beta$ fibril exposure significantly increased spike number $(\boldsymbol{C} \boldsymbol{a})$ or changes in membrane potential after $7 \mathrm{~d}$ treatment $\left(\boldsymbol{C} \boldsymbol{b},{ }^{* *} p<0.01\right.$, 1-way ANOVA).

rent injection. Oligomeric $\mathrm{A} \beta$ treatment induced a more modest but still significant increase in spike numbers (Fig. $3 \mathrm{Ba} ;{ }^{\star} \mathrm{p}<0.05$, 1-way ANOVA).

Studies done to define concentration-dependent effects of treatment with $\mathrm{A} \beta$ fibrils on primary hippocampal pyramidal neuronal excitability showed that $A \beta$ fibril exposure at 100 or $1000 \mathrm{~nm}$ was required to produce statistically significant increases in spike numbers (Fig. $3 \mathrm{Ca}$ ) and the extent of membrane potential depolarization (Fig. $3 \mathrm{Cb}$ ) in response to injection of a $90 \mathrm{pA}$ current, relative to effects of exposure to 1 or $10 \mathrm{~nm}$ fibrillar $\mathrm{A} \beta$ or scrambled $\mathrm{A} \beta$ controls $\left(n=8\right.$ for each group, ${ }^{* *} p<0.01,1$-way ANOVA).

Together, these results indicate that $\mathrm{A} \beta$-induced neuronal hyperexcitation is dependent on $\mathrm{A} \beta$ form (oligomeric or fibrillar), $\mathrm{A} \beta$ exposure duration ( $\geq 7 \mathrm{~d}$ ), and $\mathrm{A} \beta$ concentration ( $\geq 100 \mathrm{~nm}$ ).

\section{Chronic A $\beta$ exposure upregulates $\alpha 7-n A C h R$ function on} pyramidal neurons before onset of hyperactivity

Given indications for expression in the hippocampus of nAChRs, including those that contain $\alpha 7$ subunits, and for interactions
A
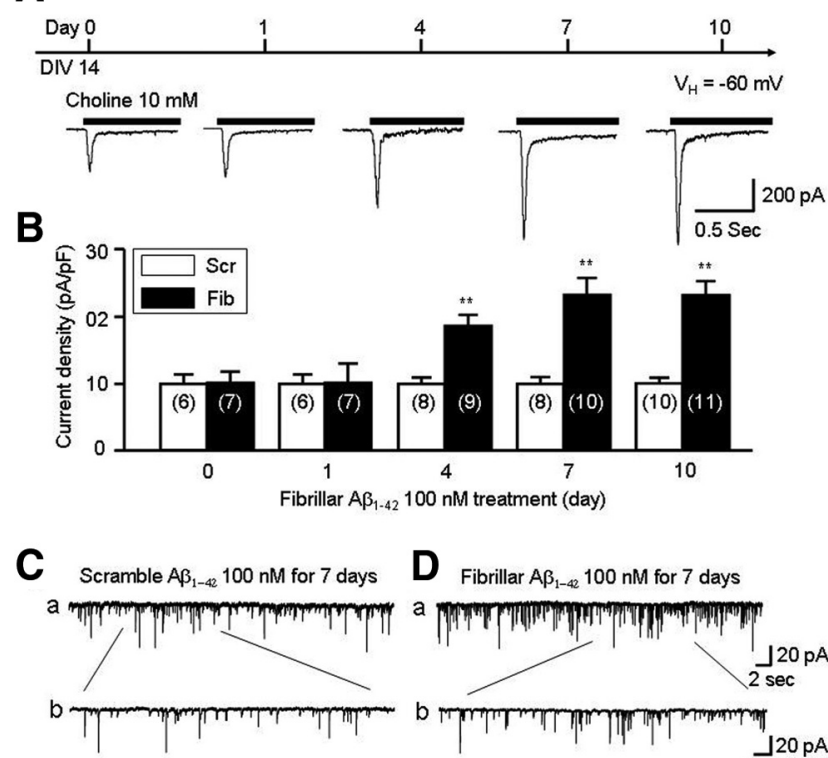

$\mathbf{E}$
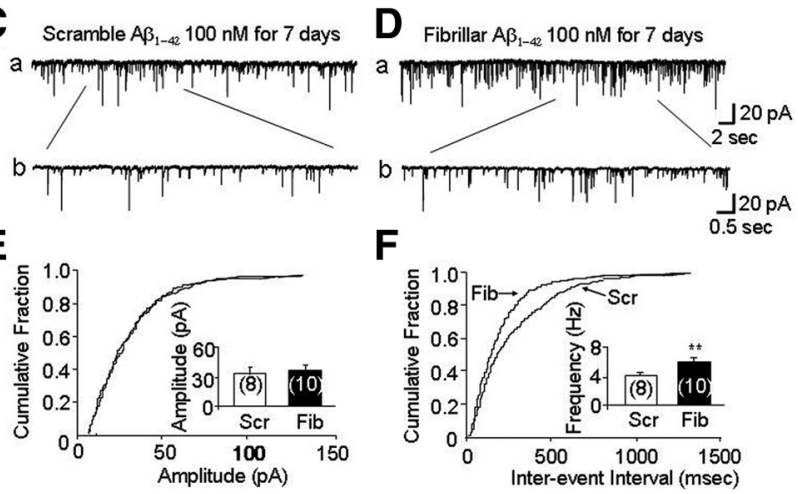

$\mathbf{F}$

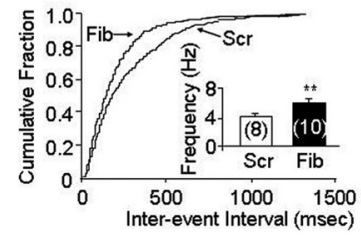

Figure 4. Chronic $A \beta$ treatment-mediated upregulation of $\alpha 7-\mathrm{nAChR}$ function and increased AMPA receptor-mediated mEPSC frequency in cultured hippocampal neurons. $A$, Representative traces of $10 \mathrm{~mm}$ choline-induced, whole-cell current responses in cultured hippocampal neurons treated with $100 \mathrm{~nm}$ ( $\mathrm{A} \beta$ monomer equivalent) fibrillar $\mathrm{A} \beta$ for the indicated periods. Note the calibration bars for duration of agonist exposure and for current amplitude. $\boldsymbol{B}$, Bar graph summarizing effects on $10 \mathrm{~mm}$ choline-induced peak current density (ordinate, $\mathrm{pA} / \mathrm{pF}$ ) from neurons treated with $100 \mathrm{~nm}$ fibrillar $\mathrm{A} \beta$ (Fib; filled bars) for the indicated periods relative to effects of scrambled (Scr; open bars) $A \beta$. Effects on heightened sensitivity to $A \beta$ emerge after $4 \mathrm{~d}$ of treatment. $C, D$, Mature, cultured hippocampal neurons (DIV 14) were treated with $100 \mathrm{~nm}$ ( $\mathrm{A} \beta$ monomer equivalent) scrambled (C, Scr) or fibrillar (D, Fib) $\mathrm{A} \beta$ for $7 \mathrm{~d}$ starting on 14 DIV. Sample traces are shown of AMPA receptor-mediated mEPSCs recorded in the presence of $0.5 \mu \mathrm{M}$ TTX, $50 \mu \mathrm{MD}-\mathrm{APV}$, or $100 \mu \mathrm{m}$ picrotoxin to block voltage-gated sodium channels, NMDA receptors, or GABA receptors, respectively, over longer $(\boldsymbol{a})$ or shorter (b) time courses (note the time or current calibration bars). $\boldsymbol{E}, \boldsymbol{F}$, Population and (in insets) bar graphs summarizing results show no effect of fibrillar $A \beta$ (Fib; filled bars) relative to scrambled $\mathrm{A} \beta$ (Scr; open bars) on mESPC amplitude $(\boldsymbol{E})$, but there is an increase in mEPSC frequency ( $\boldsymbol{F}$; shorter interevent interval) in pyramidal neurons after treatment for $7 \mathrm{~d}$ with $A \beta$ fibrils compared with scrambled $A \beta$-treated controls ( ${ }^{* *} p<0.01, t$ test).

between those receptors and $\mathrm{A} \beta$, we next asked about the status of $\alpha 7$-nAChR function in cultured, primary pyramidal neurons under control conditions and following A $\beta$ exposure. Several studies have indicated that nAChRs, including those containing $\alpha 7$ subunits, are sensitive to acute or subchronic (exposures on the order of seconds to minutes) effects of $\mathrm{A} \beta$ (see Introduction), but more work is needed to define effects of more chronic (days of exposure) effects of $\mathrm{A} \beta$ exposure on $\alpha 7$-nAChRs. Most pyramidal neurons (43 of 48 tested) in primary hippocampal cultures exhibited $\alpha 7$-nAChR-mediated patch-clamp, whole-cell current recording responses to a selective $\alpha 7$-nAChR agonist (choline, 10 mM; Fig. 4A). Interestingly, raw magnitudes (Fig. $4 A$ ) and current densities (normalized to conductance; Fig. $4 B$ ) of responses increased when cells were treated for $\geq 4 \mathrm{~d}$ with $100 \mathrm{~nm} \mathrm{~A} \beta$ fibrils relative to effects of scrambled $A \beta$ exposure. Importantly, the upregulation in $\alpha 7$-nAChR function occurs before onset of $\mathrm{A} \beta$ 
exposure-induced neuronal hyperactivity. Interestingly, there were no significant effects of $A \beta$ exposure on levels of functional $\alpha 7$-nAChR in GAD-GFP-tagged GABAergic neurons from cultures prepared from GAD-GFP mice (data not shown), indicating that upregulation seems to occur only on pyramidal neurons.

\section{Increased mEPSC activity in A $\beta$-treated hippocampal cultures}

Because $\alpha 7$-nAChRs disposed on presynaptic nerve terminals play important roles in regulation of glutamate release (Gray et al., 1996), and because excessive glutamatergic activity could account for $\mathrm{A} \beta$ exposure-induced hyperexcitation, we measured effects of chronic $A \beta$ fibril or scrambled $A \beta$ treatment on AMPA receptor-mediated mEPSCs that occur spontaneously in cultured pyramidal neurons (in the presence of $0.5 \mu \mathrm{M}$ TTX, $50 \mu \mathrm{M}$ $\mathrm{D}-\mathrm{APV}$, and $100 \mu \mathrm{M}$ picrotoxin to block sodium channel, NMDA receptor, and $\mathrm{GABA}_{\mathrm{A}}$ receptor activity, respectively; Fig. $4 C, D$ ). We found a significant increase in mEPSC frequency, but not amplitude, after $100 \mathrm{~nm}$ fibrillar $\mathrm{A} \beta$ treatment for $7 \mathrm{~d}$, but not after treatment with scrambled $\mathrm{A} \beta$ (Fig. $4 E, F$ ). These results suggest that fibrillar $\mathrm{A} \beta$ exposure could increase presynaptic $\alpha 7$ $\mathrm{nAChR}$ function controlling vesicular glutamate release, perhaps thus contributing to $A \beta$ fibril-induced neuronal hyperexcitation.

\section{Chronic $\mathrm{A} \beta$ selectively upregulates $\alpha 7$-nAChR function}

To assess specificity of chronic $A \beta$-mediated upregulation of $\alpha 7$ $\mathrm{nAChR}$ function, and to see whether $\mathrm{A} \beta$ affected some of the many other potential mediators of hyperexcitation, we examined effects of chronic $A \beta$ on a variety of ligand-gated ion channels. As shown in Figure $5 A, B$, whole-cell current responses to $10 \mathrm{~mm}$ choline of cultured pyramidal neurons were increased, relative to effects after exposure to scrambled $A \beta$, slightly, significantly, or dramatically, respectively, following $4 \mathrm{~d}$ of exposure to $\mathrm{A} \beta$ monomers, oligomers, or fibrils. However, the whole-cell current responses to GABA, AMPA, or NMDA receptor agonist were unchanged after exposure to $100 \mathrm{~nm} A \beta$, regardless of $A \beta$ form, when parallel, quantitative assessments revealed significant increases in choline-induced currents in neurons exposed to oligomeric or fibrillar $\mathrm{A} \beta$ (Fig. $5 B$ ). These results indicate that exposure for $\geq 4 \mathrm{~d}$ to $A \beta$ aggregates, especially fibrillar $A \beta$, selectively upregulates $\alpha 7$-nAChR function on hippocampal pyramidal cells.

\section{Mechanisms of A $\beta$-induced upregulation of $\alpha 7$-nAChR cell- surface expression and function}

To elucidate possible mechanisms of $\mathrm{A} \beta$ fibril-induced upregulation of $\alpha 7$-nAChR function, we determined effects of peptide treatments on levels of nAChR $\alpha 7$ subunit mRNA and protein in primary hippocampal cultures. We found that, after treatment with $100 \mathrm{~nm}$ fibrillar $\mathrm{A} \beta$ for $4 \mathrm{~d}$, there was a significant elevation in numbers of surface $\alpha 7$-nAChRs as assessed by levels of $\alpha$-Bgt binding complex-derived $\alpha 7$ subunit protein (Fig. 6B). By contrast, there was no change in total (cell surface plus intracellular pools from cell lysates) $\alpha 7$ subunit protein levels in toxin binding-derived complexes (Fig. $6 B$ ) or in $\alpha 7$ subunit mRNA levels (Fig. 6A; there also was no effect on $\mathrm{nAChR} \beta 2$ subunit mRNA). Other studies indicated that there was no change in levels of functional $\alpha 7$-nAChRs in cultures treated for $7 \mathrm{~d}$ with the $\alpha 7$-nAChR-selective antagonist MLA (data not shown), indicating that simple inhibition of $\alpha 7$-nAChR function, as occurs in our hands upon acute-to-subchronic exposure to $\mathrm{A} \beta$ (Liu et al., 2001), does not account for $\mathrm{A} \beta$-induced upregulation of $\alpha 7$ nAChRs.
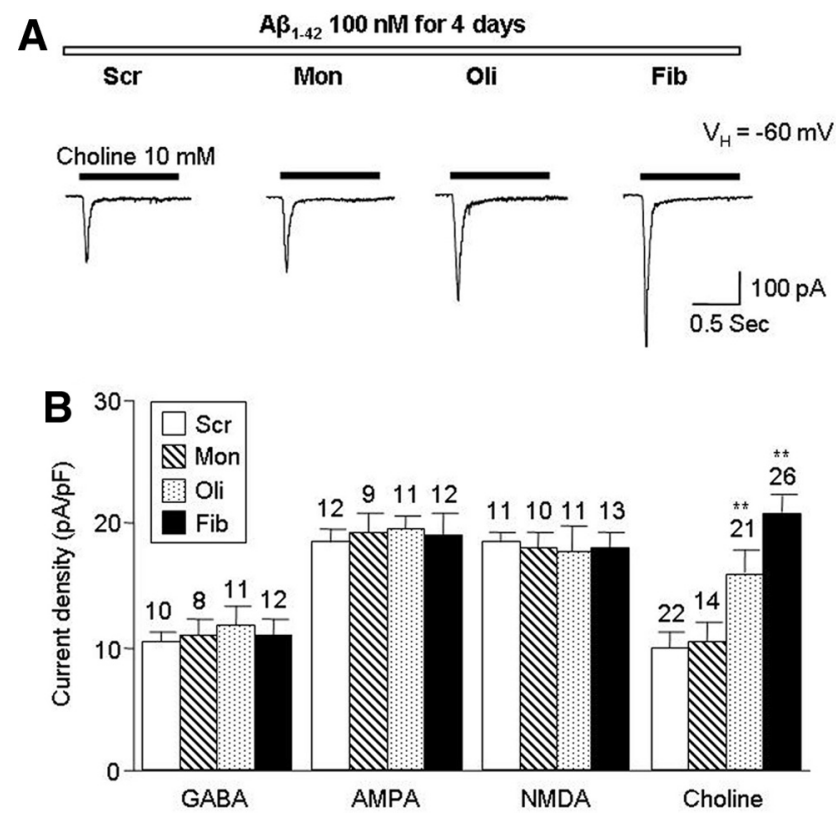

Figure 5. Specific upregulation of $\alpha 7$-nAChR function by $A \beta$ in primary cultured hippocampal neurons. $A$, Typical traces ( $-60 \mathrm{mV}$ holding potential; see current amplitude and duration of ligand application calibration scales) are shown for whole-cell current recording responses to choline ( $10 \mathrm{~mm}$ ) after $4 \mathrm{~d}$ of treatment with different forms of $100 \mathrm{~nm} \mathrm{~A} \beta$. Significant potentiation of $\alpha 7$-nAChR-mediated currents was observed after exposure to $100 \mathrm{~nm} A \beta$ oligomers (Oli) or fibrils (Fib) but not monomers (Mon), when compared with scrambled (Scr) $A \beta$ (current densities \pm SE in pA/pF:Scr, $9.8 \pm 1.4, n=22 ;$ Mon, $10.4 \pm 1.5 \mathrm{pA} / \mathrm{pF}, n=14 ; 0 l i, 15.8 \pm$ 2.3, $n=21$; Fib, $20.8 \pm 2.1, n=26$; Oli vs $S c r,{ }^{* *} p<0.01$; Fib vs $S c r,{ }^{* *} p<0.01$, 1-way ANOVA). $B$, Results are summarized for whole-cell recording peak current density in $\mathrm{pA} / \mathrm{pF}$ for responses to GABA $(0.1 \mathrm{~mm})$, AMPA $(0.1 \mathrm{~mm})$, NMDA $(0.1 \mathrm{~mm})$, or choline $(10 \mathrm{~mm})$ after $4 \mathrm{~d}$ of exposure to the indicated form of $A \beta(100 \mathrm{~nm})$. Whole-cell currents mediated by $G A B A_{A^{\prime}} A M P A$ or NMDA receptors in the same cells were not affected by treatment with different forms of $A \beta$ when choline responses were altered. These results indicate that exposure to $A \beta$ large aggregates selectively upregulates $\alpha 7$-nAChR function but not function of other ligand-gated ion channels.

To further elucidate bases for $\mathrm{A} \beta$ fibril-induced upregulation of $\alpha 7$-nAChR function and cell-surface nAChR $\alpha 7$ protein levels, we inhibited protein trafficking and monitored changes in function and surface expression of $\alpha 7$-nAChRs. We used BFA, which has been reported to inhibit transport of proteins from the endoplasmic reticulum (ER) to the Golgi (Oda et al., 1987; Broutman and Baudry, 2001). Coincubation of primary hippocampal neuronal cultures with $10 \mu \mathrm{g} / \mathrm{ml}$ BFA completely prevented the increase in $\alpha 7$-nAChR function (Fig. $6 C, D$ ) and in surface $\alpha 7$ subunit protein levels (Fig. $6 E, F$ ) induced by $4 \mathrm{~d}$ of $100 \mathrm{~nm} \mathrm{~A} \beta$ fibril treatment. These results suggest that chronic $\mathrm{A} \beta$ fibril treatment increases the trafficking of functionally capable $\alpha 7$ nAChRs from the ER to the Golgi and then on to the cell surface.

\section{$\alpha 7$-nAChR function is necessary for chronic A $\beta$-induced neuronal hyperexcitation}

Studies described above showed that the onset of increase in $\alpha 7$ $\mathrm{nAChR}$ function occurred earlier than the appearance of neuronal hyperexcitation, suggesting a causal relationship between $\mathrm{A} \beta$-induced upregulation of $\alpha 7$-nAChRs and neuronal hyperexcitation. To test the roles played by $\alpha 7$-nAChR upregulation in neuronal hyperexcitation after $A \beta$ chronic exposure, we measured neuronal excitability in hippocampal cultures prepared from nAChR $\alpha 7$ subunit KO mice or from WT mice. Interestingly, in $\mathrm{nAChR} \alpha 7$ subunit $\mathrm{KO}$ mouse hippocampal cultures, $\mathrm{A} \beta$ treatment (fibrils, $100 \mathrm{~nm}$ for $7 \mathrm{~d}$ ) failed to increase neuronal 
A

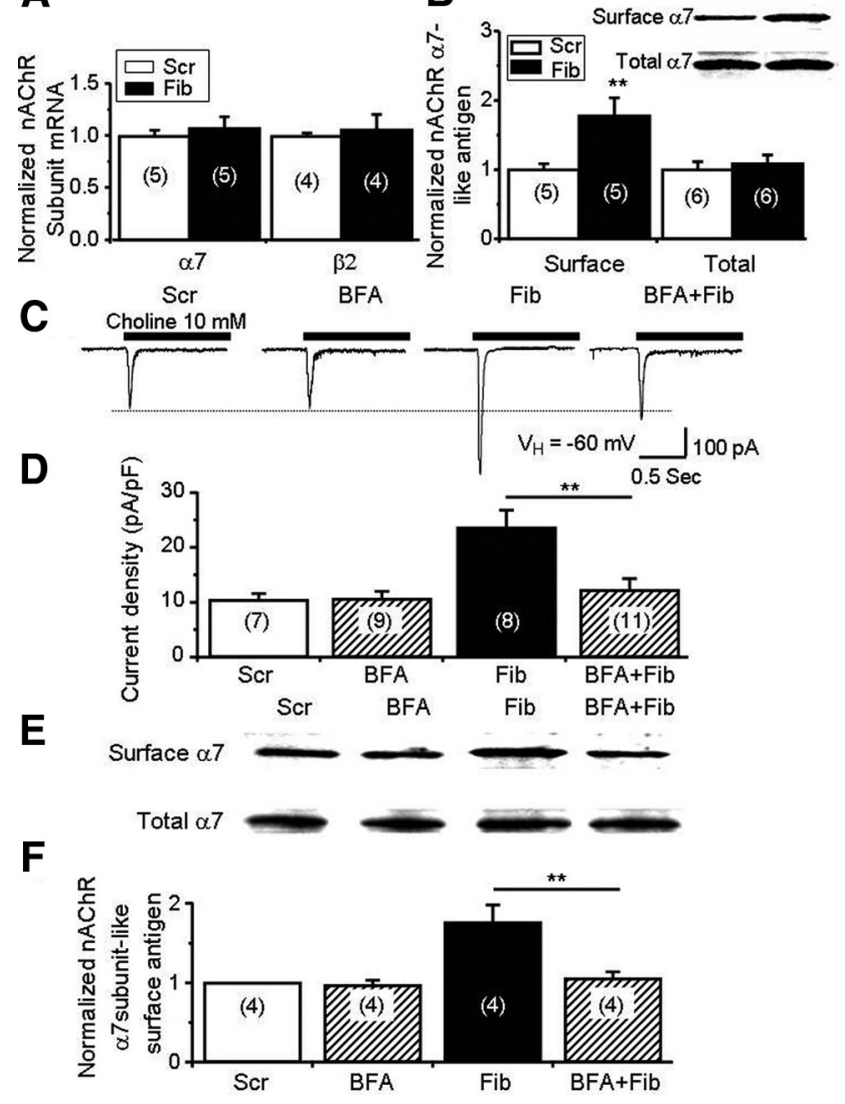

Figure 6. Mechanisms of $A \beta$ treatment-induced $\alpha 7-n A C h R$ upregulation in cultured hippocampal neurons. $\boldsymbol{A}$, Real-time RT-PCR analysis shows that $A \beta$ fibril (Fib; filled bars) exposure for $4 \mathrm{~d}$ did not alter nAChR $\alpha 7$ subunit message levels in primary hippocampal pyramidal neuron cultures relative to levels after treatment with scrambled ( $\mathrm{Scr}$; open bars) $A \beta$-treated neurons. Data in each group were internally normalized to GAPDH mRNA levels, and the lack of an effect on $\mathrm{nAChR} \beta 2$ subunit mRNA levels is shown. $\boldsymbol{B}$, Affinity purification-Western blot experiments (inset) showed that chronic exposure to fibrillar $A \beta$, relative to effects of scrambled $A \beta$, increased apparent levels of complexes on the cell surface containing nAChR $\alpha 7$ subunits capable of binding biotinylated $\alpha$-Bgt, subsequently isolated by adherence to streptavidin beads, and then reactive with anti-nAChR $\alpha 7$ subunit antibody ( $\mathrm{H} 302$, Santa Cruz Biotechnology), but not the total amount of such complexes isolated from lysed cells. The bar graph summarizes results (fibrillar $A \beta$ vs scrambled $A \beta ;{ }^{* *} p<0.01, t$ test). C, Typical whole-cell current response traces for functional activation of $\alpha 7-\mathrm{nAChR}$ by $10 \mathrm{~mm}$ choline shows that treating hippocampal pyramidal neuron cultures with BFA (10 $\mu \mathrm{g} / \mathrm{ml})$ inhibited $A \beta$ fibril exposure-induced increases in $\alpha 7-n A C h R$ function. $D$, Bar graph summaries the results of measurements of current density (ordinate, $\mathrm{pA} / \mathrm{pF}$ ) induced by $10 \mathrm{~mm}$ choline in cultured hippocampal neurons treated as indicated with scrambled ( $\mathrm{Scr}$ ) or fibrillar (Fib) $A \beta$ alone in the presence of BFA $(10 \mu \mathrm{g} / \mathrm{ml})$ and indicates that BFA exposure inhibits the $A \beta$ fibril exposure-induced increase in $\alpha 7-n A C h R$ function (fibril: $23.6 \pm 3.2, n=8$; fibril plus BFA: $12.2 \pm 2.1, n=11$; ${ }^{* *} p<0.01$, 1-way ANOVA). $E$, Treating the cultures with BFA $(10 \mu \mathrm{g} / \mathrm{ml})$ also inhibited A $\beta$ fibril exposure-induced increases in surface $\mathrm{nAChR} \alpha 7$ subunit protein expression as revealed based on affinity purification-Western analyses. $\boldsymbol{F}$, Bar graph summaries the effects on surface $\mathrm{nAChR} \alpha 7$ subunit protein levels in cultured hippocampal neurons treated as indicated. BFA (10 $\mu \mathrm{g} / \mathrm{ml}$ ) exposure inhibited $A \beta$ fibril exposure-induced increase in $\mathrm{nAChR} \alpha 7$ subunit levels on the cell surface (fibril: $176 \pm 23 \%, n=4$; fibril plus BFA: $106 \pm 8.9 \%, n=4$; ${ }^{* *} p<0.01$, 1-way ANOVA).

excitability compared with activities in WT mouse cultures (Fig. $7 A$ ). Similarly, fibrillar $A \beta$ treatment for $7 \mathrm{~d}$ in the continuous presence of 10 nM MLA also failed to increase neuronal excitability (Fig. 7A). Statistical analyses further confirmed these observations whether measuring AP frequency or changes in membrane potential in response to current injection (Fig. $7 \mathrm{~B}, C$ ). To exclude the possible roles of other nAChR subtypes (e.g., $\alpha 4 \beta 2$-nAChRs)
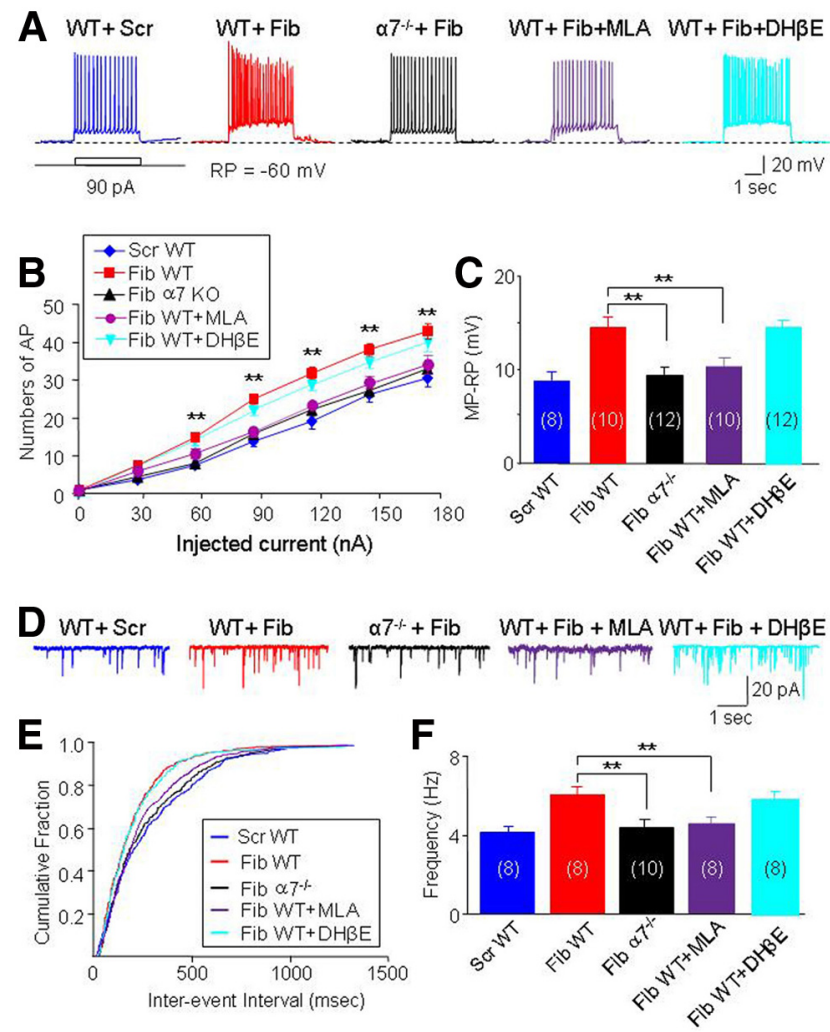

Figure 7. Roles of $\alpha 7-n A C h R$ in chronic $A \beta$ exposure-induced neuronal hyperexcitation. $A$, Typical traces of AP generation in response to $90 \mathrm{pA}$ current injection (note the $-60 \mathrm{mV}$ holding potential and the time course and membrane potential calibration bars) show that genetic deletion of $\mathrm{nAChR} \alpha 7$ subunits $\left(\alpha 7^{-1-}\right)$ or pharmacological block of $\alpha 7-\mathrm{nAChRs}$ (cochronic treatment for $7 \mathrm{~d}$ of neuronal cultures with $100 \mathrm{~nm}$ fibrillar $A \beta_{1-42}$ and $10 \mathrm{~nm} M L A$ ), but not pharmacological block of $\beta 2^{*}-n A C h R$ (via cochronic treatment with $A \beta$ and $3 \mu \mathrm{m}$ $\mathrm{DH} \beta \mathrm{E}$ for $7 \mathrm{~d}$ ), prevents neuronal hyperexcitation typically seen after $7 \mathrm{~d}$ of $100 \mathrm{~nm}$ fibrillar $A \beta$ (Fib) exposure and cultures from WT mice and more closely resembles effects of control exposure to scrambled $A \beta(S c r)$. $B$, Calculated input-output relationships for AP spike activity (ordinate) as a function of current injected $(90 \mathrm{pA})$ in cultured hippocampal neurons prepared from WT or $\alpha 7$ KO mice show that genetic deletion of $\alpha 7$-nAChR or pharmacological block of $\alpha 7$-nAChRs, but not inactivation of $\beta 2^{*}$-nAChR, prevents the increase in AP generation (number per 4 s; ordinate) $\left(^{* *} p<0.01\right.$, WT A $\beta$ fibril vs $\alpha 7$ K0 A $\beta$ fibril, or WT A $\beta$ fibril vs WT A $\beta$ fibril plus MLA, 2-way ANOVA). C, Genetic deletion or pharmacological block of $\alpha 7-n A C h R s$ also prevents the increase in changes in membrane potential relative to resting potential during current injection as typically induced by chronic fibrillar $A \beta$ exposure. Coexposure to a $\beta 2 *$ $\mathrm{nAChR}$ antagonist along with $\mathrm{A} \beta$ for $7 \mathrm{~d}$ did not prevent neuronal hyperexcitation ( $^{* *} p<0.01$, WT A $\beta$ fibril vs $\alpha 7$ KO A $\beta$ fibril, or WT A $\beta$ fibril vs WT A $\beta$ fibril plus MLA, 1-way ANOVA). $D$, Sample traces show that genetic deletion of $\alpha 7-\mathrm{nAChR}\left(\alpha 7^{-1-}\right)$ or pharmacological block of $\alpha 7$-nAChRs prevents $7 \mathrm{~d}$ fibrillar A $\beta$ (Fib) exposure-induced increases in mEPSCs recorded from cultured hippocampal pyramidal neurons and relative to control effects of exposure to scrambled $A \beta$ (Scr). $\boldsymbol{E}$, Cumulative fraction plots for mEPSC interevent intervals show that genetic deletion of $\alpha 7$-nAChR or pharmacological block of $\alpha 7-n A C h R s$, but not pharmacological block of $\beta 2^{*}-n A C h R$, prevents the increase of mEPSC frequency. $\boldsymbol{F}$, Genetic deletion or pharmacological block of $\alpha 7-n A C h R s$ with MLA, but not $\mathrm{DH} \beta \mathrm{E}$, prevents the increase of mEPSC frequency induced by chronic $A \beta$ Fibril (Fib) exposure $\left({ }^{* *} p<0.01\right.$, WT A $\beta$ fibril vs $\alpha 7$ KO A $\beta$ fibril, or WT $A \beta$ fibril vs WT $A \beta$ fibril plus MLA, 1-way ANOVA).

in $\mathrm{A} \beta$-induced hyperexcitation, we cotreated neurons with 100 nM fibrillar $\mathrm{A} \beta$ and an $\alpha 4 \beta 2$-nAChR antagonist ( $3 \mu \mathrm{M} \mathrm{DH} \beta \mathrm{E}$ ) for $7 \mathrm{~d}$. We found that $\mathrm{DH} \beta \mathrm{E}$ did not prevent $\mathrm{A} \beta$-induced hyperexcitation (Fig. $7 A-C$ ). These results suggest that $\alpha 7$-nAChR function is necessary for the initiation of chronic $\mathrm{A} \beta$-induced neuronal hyperexcitation.

In addition, we used similar genetic and pharmacological manipulations to assess whether or not $\alpha 7$-nAChRs also contribute to chronic $A \beta$-induced increases in mEPSC frequency. As dem- 
onstrated by typical recording traces shown in Figure $7 D$, treatment of hippocampal cultures in $100 \mathrm{nM} \mathrm{A} \beta$ fibrils for $7 \mathrm{~d}$, prepared either from nAChR $\alpha 7$ subunit KO mice, or from WT mice but incubated in the presence of $10 \mathrm{nM}$ MLA for those $7 \mathrm{~d}$, failed to induce a significant increase in mEPSC frequency (Fig. $7 E$ ) compared with effects seen for $\mathrm{A} \beta$-treated cultures from WT mice. Cotreatment with $\mathrm{DH} \beta \mathrm{E}(3 \mu \mathrm{M})$ for $7 \mathrm{~d}$ failed to prevent the $A \beta$-induced increase in $\mathrm{mEPSC}$ frequency (Fig. $7 D, E$ ). Current-clamp recording from the same neurons confirmed that ligand inhibition and gene knock-out effects on neuronal excitability measured as changes in membrane potential in response to current injection parallel effects on mEPSC frequency (Fig. $7 F$ ). These data indicate that upregulation of $\alpha 7$-nAChR expression and function, on pyramidal neuronal soma and proximal dendrites and/or on presynaptic glutamatergic terminals, plays an important role in $\mathrm{A} \beta$-induced neuronal hyperexcitation.

\section{Effects of short-term pharmacological blockade of $\boldsymbol{\alpha} 7$-nAChRs on A $\beta$-induced neuronal hyperexcitation and on glutamatergic hyperactivity}

Mindful of the potential therapeutic or neuroprotective use of nicotinic ligands in $\mathrm{AD}$ or its in vitro models, we next sought to determine effects of short-term nAChR manipulation on $\mathrm{A} \beta$ exposure-induced neuronal excitability of cultured pyramidal neurons. Strikingly, simple treatment with $10 \mathrm{~nm}$ MLA for $10 \mathrm{~min}$ before and continuing through and beyond recording of responses to depolarizing current injection (60 pA for $80 \mathrm{~ms}$ ) inhibited neuronal hyperexcitation otherwise seen following exposure of primary pyramidal neurons in cultures to $100 \mathrm{nM}$ fibrillar $\mathrm{A} \beta$ for $7 \mathrm{~d}$ (Fig. $8 A$ ). The inhibition of $\mathrm{A} \beta$-induced hyperexcitation was reversed following removal of MLA (Fig. 8A). Similarly, 10 min pretreatment with MLA (10 nM), but not with $\mathrm{DH} \beta \mathrm{E}(3 \mu \mathrm{M})$, reduced mEPSC activity in cultures exposed for $7 \mathrm{~d}$ to $100 \mathrm{~nm}$ fibrillar $\mathrm{A} \beta$ (Fig. $8 B$ ). This effect was due to a decrease in mEPSC frequency (increased interevent interval; Fig. $8 \mathrm{Cb}$ ) but not amplitude (Fig. $8 \mathrm{Ca}$ ). These results again indicate that functional $\alpha 7$-nAChRs play a role in maintaining hyperexcitation induced by chronic $\mathrm{A} \beta$ exposure.

\section{Discussion \\ Principal findings of this study}

We provide direct evidence for the first time that chronic exposure to pathologically relevant concentrations of $A \beta$ induces cultured hippocampal pyramidal neuron hyperexcitation. This is manifest in increases in the extent of membrane potential depolarization and in spontaneous bursting of APs in response to current injection, and it is accompanied by increased AMPA receptor-mediated $\mathrm{mEPSC}$ frequency but not amplitude, indicative of a higher probability of vesicular glutamate release. The effects are most pronounced for fibrillar $\mathrm{A} \beta$ exposure, but they also occur in the presence of $A \beta$ oligomers, and are first significant after $7 \mathrm{~d}$ of peptide exposure. Importantly, we also demonstrate that chronic exposure to $\mathrm{A} \beta$ upregulates $\alpha 7$-nAChR cell-surface expression and function via a BFA-sensitive process and before the onset of neuronal hyperexcitation. Further, we show, using pharmacological and genetic manipulations, that $\alpha 7-\mathrm{nAChR}$ function is required for manifestation of $\mathrm{A} \beta$-induced neuronal hyperexcitation. Together, our findings suggest that chronic $A \beta$-induced hyperexcitation is a pathophysiological phenotype and that $\alpha 7-\mathrm{nAChR}$ function is required for $\mathrm{A} \beta$-induced neural hyperexcitation.

\section{Time course, forms, and concentrations of $A \beta$ involved in neuronal hyperexcitation}

Studies of $A \beta$ effects on neuronal function and excitability have been seemingly contradictory (Puzzo et al., 2008; Palop and Mucke, 2010), perhaps due to differences in experimental protocols used in $\mathrm{A} \beta$ studies and variables, such as peptide concentration and form. For instance, exposure to low $\mathrm{A} \beta$ concentrations enhances, but exposure to high $\mathrm{A} \beta$ concentrations depresses, hippocampal synaptic plasticity (Puzzo et al., 2008). Oligomeric $\mathrm{A} \beta$ modulates neuronal function more dramatically than monomeric A $\beta$ (Shankar et al., 2008) and has more toxic effects (Hardy and Selkoe, 2002). Acute $\mathrm{A} \beta$ exposure depresses, but chronic $\mathrm{A} \beta$ exposure upregulates, $\alpha 7$-nAChR function (Liu et al., 2001; Yu et al., 2005). Nanomolar A $\beta$ concentrations (1-100 nM) are thought to be most pathologically relevant based on levels found in AD patients and in animal models of disease (Cirrito and Holtzman, 2003). Our results covering a range of $A \beta$ forms, concentrations, and times of exposure found the most dramatic effects occurring over a period of 4-7 d of treatment with oligomeric and, particularly, fibrillar $\mathrm{A} \beta$ at $100 \mathrm{~nm}$, which is at the high end of 
pathologically relevant $\mathrm{A} \beta$ concentrations, assuming that all concentrations are provided as monomeric $A \beta$ equivalents.

\section{Specificity of effects of A $\beta$ exposure on $\alpha 7$-nAChR expression and function and their post-translational basis}

Our studies also sought to uncover possible mechanisms involved in hippocampal circuit hyperexcitation and epileptic seizures observed in human APP mouse models of AD (Palop et al., 2007; Minkeviciene et al., 2009). A $\beta$ exhibits quite broad effects on a variety of receptors/channels in vitro, but most acute effects of $\mathrm{A} \beta$ on these targets, either on astrocytes (Abramov et al., 2004) or neurons, require much higher, micromolar concentrations of $\mathrm{A} \beta$ (Casley et al., 2009) than those seen in AD patient brains (1-100 nM) (Cirrito and Holtzman, 2003). Indeed, we found that there were no effects of several days of exposure to $100 \mathrm{nM} \mathrm{A} \beta$ fibrils on a variety of neurotransmitter-gated ion channels, including non- $\alpha 7-\mathrm{nAChR}$ subtypes or $\mathrm{GABA}_{\mathrm{A}}$, AMPA, or NMDA receptors. Prior studies suggested that $\alpha 7$-nAChRs are highly sensitive to inhibition during acute exposure to $\mathrm{A} \beta$ (Liu et al., 2001, 2009; Pettit et al., 2001). Here, we also find that chronic $A \beta$ exposure at nanomolar concentrations increases levels of expression and function of $\alpha 7$-nAChRs in hippocampal cultures. More work is required to determine whether other targets mediate $\mathrm{A} \beta$ 's effects on neuronal excitability, and increases in functional $\alpha 7$ $\mathrm{nAChR}$ levels may not be the sole process triggering $\mathrm{A} \beta$ 's effects, especially given our elucidation of increased input resistance and glutamatergic $\mathrm{mESPC}$ frequency when there is hyperexcitation. However, chronic $A \beta$ exposure-induced effects on neuronal excitability require $\alpha 7$-nAChR function and occur after there is significant upregulation of $\alpha 7$-nAChR function.

Sensitivity to BFA of the $\mathrm{A} \beta$-induced upregulation of functional and cell-surface $\alpha 7$-nAChRs indicates that the process has a post-translational basis, likely involving changes in protein trafficking and functional receptor assembly dependent upon enhanced transit of nAChR $\alpha 7$ subunits and/or assembled $\alpha 7$ nAChRs from the ER to the Golgi apparatus and not reflected in changes in nAChR $\alpha 7$ subunit mRNA levels. Interestingly, this finding is not entirely consistent with observations that there is elevated expression of $\alpha 7$ subunits as mRNA in both $\mathrm{AD}$ patients and AD animal models (Hellström-Lindahl et al., 1999; Chu et al., 2005; Counts et al., 2007), but the latter studies took a more global and long-term approach to assessing effects in brain tissues than did our studies focusing on hippocampal neuronal cultures. Studies showing no effects of chronic MLA exposure alone on levels of functional $\alpha 7$-nAChR indicate that upregulation cannot simply reflect adaptation to inhibition of $\alpha 7-n A C h R s$, so other mechanisms must be involved in $\mathrm{A} \beta$ fibril-induced upregulation of $\alpha 7$-nAChR.

\section{Roles of $\alpha 7-\mathrm{nAChRs}$ in AD pathogenesis and therapy}

Previous work, including ours, showed inhibitory effects of acute $\mathrm{A} \beta$ exposure on heterologously or naturally expressed $\alpha 7$ nAChRs in cultured cells or brain slices (Liu et al., 2001, 2009; Pettit et al., 2001; Lamb et al., 2005). A recent study also reveals that $\alpha 7$-nAChR-dependent synaptic plasticity in the hippocampus can be disrupted by acute $A \beta$ exposure (Gu and Yakel, 2011). There is not unanimity in these kinds of studies, as there are reports of activating effects of acute $\mathrm{A} \beta$ on $\alpha 7$-nAChRs heterologously expressed in oocytes (Dineley et al., 2002) or on native, non- $\alpha 7$-nAChRs (Fu and Jhamandas, 2003). However, reported increases in $\alpha 7$ subunit mRNA or protein in human AD or in mouse models of the disease (Hellström-Lindahl et al., 1999; Chu et al., 2005; Counts et al., 2007) could be taken as evidence for receptor upregulation triggered by inhibition of $\alpha 7$-nAChRs by chronic $\mathrm{A} \beta$ exposure. On the other hand, levels of $\alpha 7$-nAChR function have been reported to be comparable in adult, APP transgenic, or WT mice (Spencer et al., 2006). Nevertheless, given that activation of $\alpha 7$-nAChRs appears to significantly enhance cognitive function (Levin and Rezvani, 2002), it has been suggested that acute $\mathrm{A} \beta$-mediated inhibition of $\alpha 7$-nAChR function could contribute to cholinergic signaling deficits and cognitive decline in $\mathrm{AD}$ and that enhancement of $\alpha 7-\mathrm{nAChR}$ function would be a viable, therapeutic strategy in treatment of $\mathrm{AD}$ (Buccafusco et al., 2005; Buckingham et al., 2009).

However, our data challenge this concept. By contrast to most recent studies concerning effects of acute $A \beta$ treatment, our findings indicate that function of overexpressed $\alpha 7-\mathrm{nAChR}$ is required for manifestation of effects of chronic $\mathrm{A} \beta$ fibril exposure: effects are not seen in mice lacking $\alpha 7$ subunits, on subchronic inhibition of $\alpha 7$-nAChR function, or-by operational definition-in control cultures not exposed to $\mathrm{A} \beta$ and thus expressing baseline levels of $\alpha 7$-nAChR. We suggest that upregulation of highly calcium-permeable $\alpha 7$-nAChR expression and function on glutamatergic presynaptic terminals could lead to increased glutamatergic release responsible for the increased glutamate mEPSC frequency seen in $A \beta$-treated cultures. Other possible mechanisms cannot be ruled out (Ping and Tsunoda, 2012) and warrant further investigation, but we propose a new hypothesis that, in $\mathrm{AD}$ brain, aberrantly high deposition of $\mathrm{A} \beta$ upregulates $\alpha 7$-nAChR expression and function, in turn inducing neural hyperexcitation, perhaps epileptic seizures, and consequent neurotoxicity. If this hypothesis is true, then $\alpha 7$-nAChR antagonists should be considered as a potential therapeutic strategy for $\mathrm{AD}$ therapy. This idea also is consistent with recent findings that genetic deletion of nAChR $\alpha 7$ subunits significantly rescues synaptic impairment and learning/memory deficits in older, APP mice (Dziewczapolski et al., 2009). However, $\alpha 7$-nAChRmediated effects may critically depend on animal age (and perhaps background), because one recent study (Hernandez et al., 2010), using a mouse model of AD, suggests that deletion of $\alpha 7$ subunits exacerbates learning deficits in young animals and alters the pattern of $\mathrm{A} \beta$ accumulation.

Further studies are required to distinguish possibly agedependent roles of $\alpha 7$-nAChR in the pathogenesis of $\mathrm{AD}$ in vivo. However, our findings strongly suggest that $\mathrm{A} \beta$-induced, elevated $\alpha 7$-nAChR function is required for neural hyperexcitation. Perhaps elevated $\alpha 7$-nAChR function also contributes to elevated seizure activity seen in $\mathrm{AD}$ and possibly excitotoxicity and ultimate cognitive deficits observed in AD. Most importantly, the current findings suggest that inhibition instead of activation of $\alpha 7$-nAChR function might be a novel and productive therapeutic strategy to slow or prevent progression and/or consequences of $\mathrm{AD}$ in older subjects.

\section{References}

Abramov AY, Canevari L, Duchen MR (2004) Calcium signals induced by amyloid beta peptide and their consequences in neurons and astrocytes in culture. Biochim Biophys Acta 1742:81-87. CrossRef Medline

Alkondon M, Albuquerque EX (1995) Diversity of nicotinic acetylcholine receptors in rat hippocampal neurons. III. Agonist actions of the novel alkaloid epibatidine and analysis of type II current. J Pharmacol Exp Ther 274:771-782. Medline

Amatniek JC, Hauser WA, DelCastillo-Castaneda C, Jacobs DM, Marder K, Bell K, Albert M, Brandt J, Stern Y (2006) Incidence and predictors of seizures in patients with Alzheimer's disease. Epilepsia 47:867-872. CrossRef Medline

Bertrand D, Bertrand S, Ballivet M (1992) Pharmacological properties of the homomeric alpha 7 receptor. Neurosci Lett 146:87-90. CrossRef Medline 
Broide RS, Salas R, Ji D, Paylor R, Patrick JW, Dani JA, De Biasi M (2002) Increased sensitivity to nicotine-induced seizures in mice expressing the L250T alpha 7 nicotinic acetylcholine receptor mutation. Mol Pharmacol 61:695-705. CrossRef Medline

Broutman G, Baudry M (2001) Involvement of the secretory pathway for AMPA receptors in NMDA-induced potentiation in hippocampus. J Neurosci 21:27-34. Medline

Buccafusco JJ, Letchworth SR, Bencherif M, Lippiello PM (2005) Longlasting cognitive improvement with nicotinic receptor agonists: mechanisms of pharmacokinetic-pharmacodynamic discordance. Trends Pharmacol Sci 26:352-360. CrossRef Medline

Bucciantini M, Giannoni E, Chiti F, Baroni F, Formigli L, Zurdo J, Taddei N, Ramponi G, Dobson CM, Stefani M (2002) Inherent toxicity of aggregates implies a common mechanism for protein misfolding diseases. Nature 416:507-511. CrossRef Medline

Buckingham SD, Jones AK, Brown LA, Sattelle DB (2009) Nicotinic acetylcholine receptor signalling: roles in Alzheimer's disease and amyloid neuroprotection. Pharmacol Rev 61:39-61. CrossRef Medline

Busche MA, Eichhoff G, Adelsberger H, Abramowski D, Wiederhold KH, Haass C, Staufenbiel M, Konnerth A, Garaschuk O (2008) Clusters of hyperactive neurons near amyloid plaques in a mouse model of Alzheimer's disease. Science 321:1686-1689. CrossRef Medline

Casley CS, Lakics V, Lee HG, Broad LM, Day TA, Cluett T, Smith MA, O’Neill MJ, Kingston AE (2009) Up-regulation of astrocyte metabotropic glutamate receptor 5 by amyloid-beta peptide. Brain Res 1260:65-75. CrossRef Medline

Charpantier E, Wiesner A, Huh KH, Ogier R, Hoda JC, Allaman G, Raggenbass M, Feuerbach D, Bertrand D, Fuhrer C (2005) $\alpha 7$ Neuronal nicotinic acetylcholine receptors are negatively regulated by tyrosine phosphorylation and Src-family kinases. J Neurosci 25:9836-9849. CrossRef Medline

Chu LW, Ma ES, Lam KK, Chan MF, Lee DH (2005) Increased alpha 7 nicotinic acetylcholine receptor protein levels in Alzheimer's disease patients. Dement Geriatr Cogn Disord 19:106-112. CrossRef Medline

Cirrito JR, Holtzman DM (2003) Amyloid beta and Alzheimer disease therapeutics: the devil may be in the details. J Clin Invest 112:321-323. CrossRef Medline

Cleary JP, Walsh DM, Hofmeister JJ, Shankar GM, Kuskowski MA, Selkoe DJ, Ashe KH (2005) Natural oligomers of the amyloid-beta protein specifically disrupt cognitive function. Nat Neurosci 8:79-84. CrossRef Medline

Counts SE, He B, Che S, Ikonomovic MD, DeKosky ST, Ginsberg SD, Mufson EJ (2007) Alpha7 nicotinic receptor up-regulation in cholinergic basal forebrain neurons in Alzheimer disease. Arch Neurol 64:1771-1776. CrossRef Medline

Dani JA (2000) Properties underlying the influence of nicotinic receptors on neuronal excitability and epilepsy. Epilepsia 41:1063-1065. CrossRef Medline

Del Vecchio RA, Gold LH, Novick SJ, Wong G, Hyde LA (2004) Increased seizure threshold and severity in young transgenic CRND8 mice. Neurosci Lett 367:164-167. CrossRef Medline

Desai NS, Rutherford LC, Turrigiano GG (1999) Plasticity in the intrinsic excitability of cortical pyramidal neurons. Nat Neurosci 2:515-520. CrossRef Medline

De Simoni A, Yu LM (2006) Preparation of organotypic hippocampal slice cultures: interface method. Nat Protoc 1:1439-1445. CrossRef Medline

Dineley KT, Bell KA, Bui D, Sweatt JD (2002) Beta-amyloid peptide activates alpha 7 nicotinic acetylcholine receptors expressed in Xenopus oocytes. J Biol Chem 277:25056-25061. CrossRef Medline

Dziewczapolski G, Glogowski CM, Masliah E, Heinemann SF (2009) Deletion of the $\alpha 7$ nicotinic acetylcholine receptor gene improves cognitive deficits and synaptic pathology in a mouse model of Alzheimer's disease. J Neurosci 29:8805-8815. CrossRef Medline

Fan Y, Deng P, Wang YC, Lu HC, Xu ZC, Schulz PE (2008) Transient cerebral ischemia increases CA1 pyramidal neuron excitability. Exp Neurol 212:415-421. CrossRef Medline

Fu W, Jhamandas JH (2003) Beta-amyloid peptide activates nonalpha7 nicotinic acetylcholine receptors in rat basal forebrain neurons. J Neurophysiol 90:3130-3136. CrossRef Medline

Goedert M, Spillantini MG (2006) A century of Alzheimer's disease. Science 314:777-781. CrossRef Medline

Gray R, Rajan AS, Radcliffe KA, Yakehiro M, Dani JA (1996) Hippocampal synaptic transmission enhanced by low concentrations of nicotine. $\mathrm{Na}$ ture 383:713-716. CrossRef Medline

Gu Z, Yakel JL (2011) Timing-dependent septal cholinergic induction of dynamic hippocampal synaptic plasticity. Neuron 71:155-165. CrossRef Medline

Hardy J, Selkoe DJ (2002) The amyloid hypothesis of Alzheimer's disease: progress and problems on the road to therapeutics. Science 297:353-356. CrossRef Medline

He P, Liu Q, Wu J, Shen Y (2012) Genetic deletion of TNF receptor suppresses excitatory synaptic transmission via reducing AMPA receptor synaptic localization in cortical neurons. FASEB J 26:334-345. CrossRef Medline

Hellström-Lindahl E, Mousavi M, Zhang X, Ravid R, Nordberg A (1999) Regional distribution of nicotinic receptor subunit mRNAs in human brain: comparison between Alzheimer and normal brain. Brain Res Mol Brain Res 66:94-103. CrossRef Medline

Hernandez CM, Kayed R, Zheng H, Sweatt JD, Dineley KT (2010) Loss of $\alpha 7$ nicotinic receptors enhances $\beta$-amyloid oligomer accumulation, exacerbating early-stage cognitive decline and septohippocampal pathology in a mouse model of Alzheimer's disease. J Neurosci 30:2442-2453. CrossRef Medline

Hommet C, Mondon K, Camus V, De Toffol B, Constans T (2008) Epilepsy and dementia in the elderly. Dement Geriatr Cogn Disord 25:293-300. CrossRef Medline

Ikonomovic MD, Wecker L, Abrahamson EE, Wuu J, Counts SE, Ginsberg SD, Mufson EJ, Dekosky ST (2009) Cortical alpha7 nicotinic acetylcholine receptor and beta-amyloid levels in early Alzheimer disease. Arch Neurol 66:646-651. CrossRef Medline

Karmarkar UR, Buonomano DV (2006) Different forms of homeostatic plasticity are engaged with distinct temporal profiles. Eur J Neurosci 23: 1575-1584. CrossRef Medline

Lamb PW, Melton MA, Yakel JL (2005) Inhibition of neuronal nicotinic acetylcholine receptor channels expressed in Xenopus oocytes by betaamyloid1-42 peptide. J Mol Neurosci 27:13-21. CrossRef Medline

Leonard AS, McNamara JO (2007) Does epileptiform activity contribute to cognitive impairment in Alzheimer's disease? Neuron 55:677-678. CrossRef Medline

Levin ED, Rezvani AH (2002) Nicotinic treatment for cognitive dysfunction. Curr Drug Targets CNS Neurol Disord 1:423-431. CrossRef Medline

Liu Q, Kawai H, Berg DK (2001) Beta-amyloid peptide blocks the response of alpha 7-containing nicotinic receptors on hippocampal neurons. Proc Natl Acad Sci U S A 98:4734-4739. CrossRef Medline

Liu Q, Huang Y, Xue F, Simard A, DeChon J, Li G, Zhang J, Lucero L, Wang M, Sierks M, Hu G, Chang Y, Lukas RJ, Wu J (2009) A novel nicotinic acetylcholine receptor subtype in basal forebrain cholinergic neurons with high sensitivity to amyloid peptides. J Neurosci 29:918-929. CrossRef Medline

McKay BE, Placzek AN, Dani JA (2007) Regulation of synaptic transmission and plasticity by neuronal nicotinic acetylcholine receptors. Biochem Pharmacol 74:1120-1133. CrossRef Medline

Minkeviciene R, Rheims S, Dobszay MB, Zilberter M, Hartikainen J, Fülöp L, Penke B, Zilberter Y, Harkany T, Pitkänen A, Tanila H (2009) Amyloid $\beta$-induced neuronal hyperexcitability triggers progressive epilepsy. J Neurosci 29:3453-3462. CrossRef Medline

Mongiat LA, Espósito MS, Lombardi G, Schinder AF (2009) Reliable activation of immature neurons in the adult hippocampus. PLoS One 4:e5320. CrossRef Medline

Oda K, Hirose S, Takami N, Misumi Y, Takatsuki A, Ikehara Y (1987) Brefeldin A arrests the intracellular transport of a precursor of complement C3 before its conversion site in rat hepatocytes. FEBS Lett 214:135138. CrossRef Medline

Palop JJ, Mucke L (2009) Epilepsy and cognitive impairments in Alzheimer disease. Arch Neurol 66:435-440. CrossRef Medline

Palop JJ, Mucke L (2010) Synaptic depression and aberrant excitatory network activity in Alzheimer's disease: two faces of the same coin? Neuromolecular Med 12:48-55. CrossRef Medline

Palop JJ, Chin J, Roberson ED, Wang J, Thwin MT, Bien-Ly N, Yoo J, Ho KO, Yu GQ, Kreitzer A, Finkbeiner S, Noebels JL, Mucke L (2007) Aberrant excitatory neuronal activity and compensatory remodeling of inhibitory hippocampal circuits in mouse models of Alzheimer's disease. Neuron 55:697-711. CrossRef Medline 


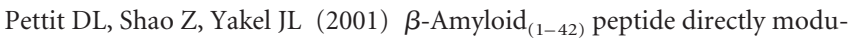
lates nicotinic receptors in the rat hippocampal slice. J Neurosci 21: RC120. Medline

Ping Y, Tsunoda S (2012) Inactivity-induced increase in nAChRs upregulates Shal $\mathrm{K}(+)$ channels to stabilize synaptic potentials. Nat Neurosci 15:90-97. Medline

Puzzo D, Privitera L, Leznik E, F à M, Staniszewski A, Palmeri A, Arancio O (2008) Picomolar amyloid- $\beta$ positively modulates synaptic plasticity and memory in hippocampus. J Neurosci 28:14537-14545. CrossRef Medline

Shankar GM, Li S, Mehta TH, Garcia-Munoz A, Shepardson NE, Smith I, Brett FM, Farrell MA, Rowan MJ, Lemere CA, Regan CM, Walsh DM, Sabatini BL, Selkoe DJ (2008) Amyloid-beta protein dimers isolated directly from Alzheimer's brains impair synaptic plasticity and memory. Nat Med 14:837-842. CrossRef Medline

Spencer JP, Weil A, Hill K, Hussain I, Richardson JC, Cusdin FS, Chen YH, Randall AD (2006) Transgenic mice overexpressing human beta-amyloid have functional nicotinic alpha 7 receptors. Neuroscience 137:795-805. CrossRef Medline

Stoppini L, Buchs PA, Muller D (1991) A simple method for organotypic cultures of nervous tissue. J Neurosci Methods 37:173-182. CrossRef Medline
Tsai J, Grutzendler J, Duff K, Gan WB (2004) Fibrillar amyloid deposition leads to local synaptic abnormalities and breakage of neuronal branches. Nat Neurosci 7:1181-1183. CrossRef Medline

Wang HY, Stucky A, Liu J, Shen C, Trocme-Thibierge C, Morain P (2009) Dissociating $\beta$-amyloid from $\alpha 7$ nicotinic acetylcholine receptor by a novel therapeutic agent, S 24795, normalizes $\alpha 7$ nicotinic acetylcholine and NMDA receptor function in Alzheimer's disease brain. J Neurosci 29:10961-10973. CrossRef Medline

Westmark CJ, Westmark PR, Beard AM, Hildebrandt SM, Malter JS (2008) Seizure susceptibility and mortality in mice that over-express amyloid precursor protein. Int J Clin Exp Pathol 1:157-168. Medline

Xiu J, Nordberg A, Zhang JT, Guan ZZ (2005) Expression of nicotinic receptors on primary cultures of rat astrocytes and up-regulation of the alpha7, alpha4 and beta2 subunits in response to nanomolar concentrations of the beta-amyloid peptide(1-42). Neurochem Int 47:281-290. CrossRef Medline

Yu WF, Guan ZZ, Bogdanovic N, Nordberg A (2005) High selective expression of alpha7 nicotinic receptors on astrocytes in the brains of patients with sporadic Alzheimer's disease and patients carrying Swedish APP 670/671 mutation: a possible association with neuritic plaques. Exp Neurol 192:215-225. CrossRef Medline 